\title{
Evaluation of a Power Driven Residue Manager for No-till Drills
}

\author{
Hegazy R. A. ${ }^{1}$ and Dhaliwal I. S. ${ }^{2}$ \\ ${ }^{1}$ Lecturer, Agricultural Engineering Department, Kafrelsheikh University, Egypt. \\ rashad.hegazy@agr.kfs.edu.eg \\ ${ }^{2}$ Professor, Farm Power \& Machinery Department, Punjab Agricultural University. \\ Ludhiana, India.
}

\begin{abstract}
The main operational problem in direct drilling of paddy straw residue is the accumulation and wrapping of loose straw within/on the tines and frame of no-till drills and traction problems with the ground wheel. A residue management equipment (RME) is developed to cut and remove paddy straw away from furrow openers of the no-till drill. The equipment consisted of nine parts; each part consisted of two powered wheels, one wheel for cutting the residue and the other wheel for removing them away from notill drill furrow openers. This equipment was attached with the no-till drill with inverted "T" type furrow opener and the experiments have been conducted to compare the no-till drill with RME and same no-till drill without RME. No-till drill with RME increased the fuel consumption and time required by $29.6 \%$ and $13.14 \%$, respectively. Adding RME to the no-till drill decreased the amount of residue clogged by $33 \%$ and increased the percentage of cut hill from 14.9 to $63.7 \%$. The average numbers of effective tiller, spike length and plant heights were more for no-till drill with RME. Furthermore, the grain yield was increased by $12.4 \%$ for fields with no-drill with RME.
\end{abstract}

Keywords: Residue Management Equipment, No-till Drill, Paddy Field Residue, Power-Driven, India

\section{INTRODUCTION}

Crop residues on the soil surface makes uniform seedling establishment difficult in conservation tillage systems, in addition high levels of crop residues present a constraint to the adoption of conservation tillage because residues mechanically interfere with seeding operations. Improved seeding equipment or residue removal may be necessary for successful direct drilling practices (Carter, 1994; Manjeet and Shukla, 2006 and Siemens \& Wilkins, 2006).

The collection of straw after paddy harvesting is uneconomical and its end use is not yet wide spread. So either residue is incorporated in the soil or burnt in the field. Incorporation of straw in soil has got some advantages in improving the soil fertility and yield. But this process needs many operations which involves both time and money of the farmers and it delays sowing of wheat crop. The wheat production is adversely affected if crop is not sown in time. It has been reported that wheat yield decreases by $35-40 \mathrm{~kg} / \mathrm{ha}$ per day, when wheat is not sown before November 30 (Singh and Singh, 1995). There may be several reasons for delayed sowing, but using direct drilling 
systems can reduce most of those reasons. In addition Indian economy would gain around 1800 million dollar in net present value over the next 30 years from the adoption of no-till in the rice-wheat areas of north-western India (Vincent and Quirke, 2002).

In heavy crop residue or when row spacing is narrow, Hoe, chisel, winged chisel, and inverted "T" type drills are prone to blockages between adjacent openers (Wilkins et al. 1983 and Slattery, 1998), causing operator frustration and reducing field capacity. They also tend to cause large clumps of residue to form (Slattery and Riley, 1996), which cover the crop row and choke out young seedlings. Another problem with these types used in drills is that the furrow opening shank disturbs the soil with sufficient force that the uncontrolled soil is thrown out of the seed furrow and occasionally onto the adjacent seed row. This adversely affects seeding depth uniformity, which is important for optimum seedling emergence and maximum yield of many crops, including cereals (Morrison and Gerik, 1985).

Equipment modifications to overcome these problems have included mounting a residue cutting coulter ahead of each furrow opener, increasing the spacing between openers by either increasing row spacing and/or adding ranks of toolbars to improve residue flow, utilizing row cleaning devices to move residue away from the furrow, and adding rolling shields next to each furrow opener to reduce soil throw. But many drawbacks include being prone to damage in rocky soils and significantly increasing draft forces and therefore tractor power requirements, they also increase cluttering within the implement frame and therefore promote drill plugging when used in high residue densities.

An approach that has not been well explored is the use of powered devices to move the residue. One of existing power residue cutting system is a powered-disc ridge till with no-till planter, it was designed to solve the problems of straw blocking, high energy consumption of strip rototilling and unstable operation on ridges in current no-tillage maize planting in ridge tillage areas of northeast China. The machine used the combined device of powered-disc and depth control wheel to cut the stubble, open seed furrow and stabilize in planting, and the key parameters of the device were analyzed and determined. The powered-disc ridge till and no-till planter reduced fuel consumption by $8.5 \%$ and soil disturbance by $50 \%$,respectively compared to the strip rototilling ridge till and no-till planter(Wang et al., 2008). From above mentioned review, more studies are required to highlight the advantage of using power residue managers.

\section{THEORETICAL CONSIDERATIONS AND CONCEPTS FOR THE RESIDUE MANAGEMENT EQUIPMENT}

The residue management equipment (RME) was developed on the basis of cutting and removing of paddy straw away from the no-till drill. In order to facilitate the movement of straw, two processes are needed one for cutting the residue and the other for removing them. The significance of the residue cutting include reducing the length of loose straw and cutting stand stable which may be laying in front of no-till drill but still connected with the soil. Removing the residue is necessary to reduce the amount of

R. A. Hegazy and I. S. Dhaliwal. Evaluation of a Power Driven Residue Manager for No-till Drills. Agricultural Engineering International: the CIGR Journal. Manuscript No.1641. Vol. 13, No.1, 2011. Provisional PDF Version. 
residue clogged on furrow openers and make the line of sowing clear and clean from residue which affects no-till drill performance. The residue management device was power driven to overcome the problems found with using passive devices.

The design of cutting wheel is based on the idea that using star shape wheel (teeth) would essentially work as a narrow tool, but with a forward and rake angle (McKyes, 1985). During soil-wheel contact, the wheel will be provided with greater momentum than that obtained with a smooth, waved, notched and ripple edged which commonly used to cut plant residues, beside reducing the amount of soil throw (Desbiolles, 2004). Besides, the wheel would penetrate the soil more easily and require less vertical force. The toothed wheel will cut the residues only if it penetrates the soil with little depth and rotates. This will happen only if there is enough vertical pressure from the wheel and a corresponding soil resistance to the draught force due to the action of the teeth. This can happen if we provide a power source to rotate the wheel with specific rotating speed and fixed position.

For adjust the suitable distance between two consecutive teeth, one tooth should touch the residue surface when the previous one penetrate the soil as shown in Figure 1 (Bianchini, 2002).

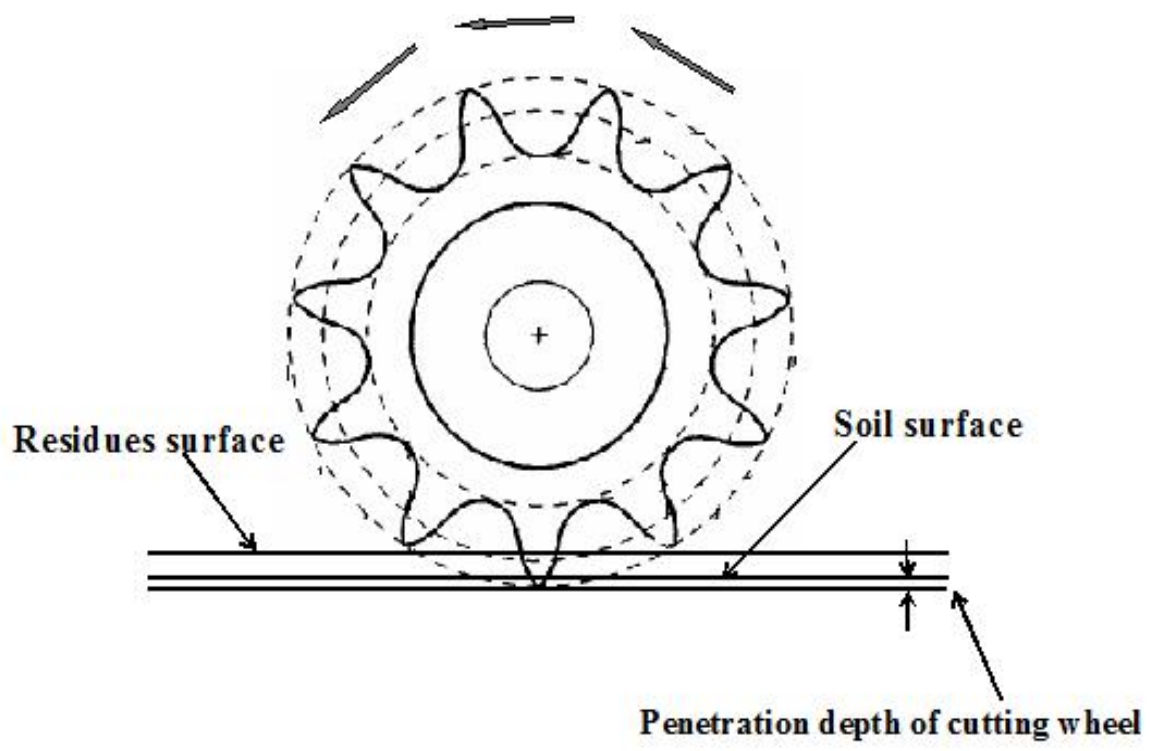

Figure 1. Cutting wheel related to soil and residue surfaces.

For designing the cutting wheel under above consideration, the calculation and assumptions based on standard machine design books were followed. The final geometry of cutting wheel generated by using Solid work design programme and the suitable number of teeth was 12 with $50 \mathrm{~mm}$ length for each edge. The removing wheel designed according to the fact that the residue can move away from furrow opener if proper fingers (plugs) operated with suitable angle (the angle between the wheel and the line of travel. (Dawn Company, 2001 and Yetter, 2003). Another concept is that the finger used should be curved, that is help on removing the residue (Siemens et al., 2004).

R. A. Hegazy and I. S. Dhaliwal. Evaluation of a Power Driven Residue Manager for No-till Drills. Agricultural Engineering International: the CIGR Journal. Manuscript No.1641. Vol. 13, No.1, 2011. Provisional PDF Version. 
To design present removing wheel, both curved fingers and wheel angle should take in consideration with adjusting the dimensions to attach this wheel with the cutting wheel. The diameter of removing wheel is less than the diameter of cutting by $2 \mathrm{~cm}$ to prevent soil-wheel interaction. The distance between to fingers adjusted to avoid accumulation of the residue. The number of the finger used to manufacture the removing wheel was 18 with $50 \mathrm{~mm}$ length and $40 \mathrm{~mm}$ width. The fingers were curved with 15 degree to as recommended from review. The overall diameter was $280 \mathrm{~mm}$ and the fingers spaced equally around its perimeter. The material used for manufacturing the removing wheel was mild steel with $4 \mathrm{~mm}$ thickness, using mild steel in manufacturing the unit because its is cheap, wide variety available with different properties, has high stiffness, magnetic and are easy to weld. However carbon heat treated steel can be used if we looking retaining sharpness much longer when working in the soil residue.

Both cutting wheel and removing wheel attached together in one unit as double wheel for testing in soil bin as shown in Figure 2.

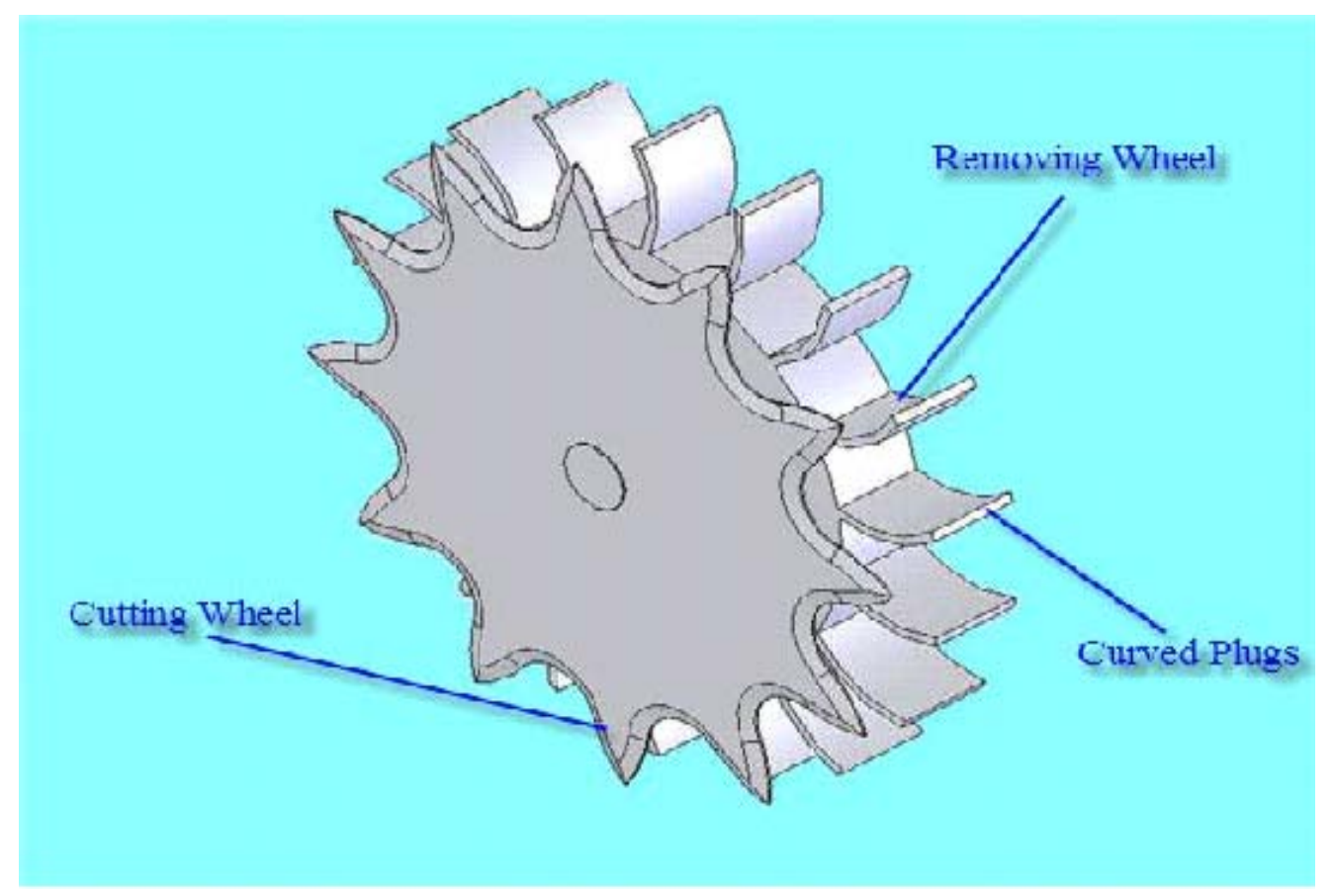

Figure 2. Geometry of the powered residue management device.

\section{MATERIALS AND METHODS}

\subsection{Manufacturing the Residue Management Equipment}

The RME was consisted of nine parts; each part was consisted of two powered wheels; one wheel for cutting the residue and the other wheel for removing them. The cutting wheel had 300 and $200 \mathrm{~mm}$ outside and root diameter, respectively. The suitable number of toothed edges was 12 with $50 \mathrm{~mm}$ length for each edge. The circular pitch 
and Pitch diameter for this wheel were 65 and $250 \mathrm{~mm}$, respectively. The material used to manufacture the cutting wheel was mild steel $4 \mathrm{~mm}$ thick. The overall diameter for removing wheel was $280 \mathrm{~mm}$ and the number of the fingers used to manufacture the removing wheel was 18 with $50 \mathrm{~mm}$ length and $40 \mathrm{~mm}$ width. The fingers were curved with 15 degree and spaced equally around its perimeter. An angle of 20 degree (between the line of travel and the fingers) was considered to improve the removing process. The material used for manufacturing the removing wheel was mild steel $4 \mathrm{~mm}$ thick. The distance between adjacent fingers was adjusted to avoid accumulation of residue.

The manufactured cutting and removing wheels were attached together with $30 \mathrm{~mm}$ spacing between the two wheels. All parts were mounted on one shaft which designed to carry the RME (Fig. 3). The shaft was designed after measuring the torque and power requirement and it made from C45 (C45 grade carbon steel) with 60 and 55mm outer and inner diameter respectively. Required RPM for the RME was around 200 RPM. The residue management parts were equally distributed on the shaft with 200 $\mathrm{mm}$ between every part (recommended row spacing for wheat).

\subsection{Attaching the Residue Management Equipment with No-till Drill}

Attachment of the residue management device with no-till drill done by using a frame had $200 \mathrm{~mm}$ length, $450 \mathrm{~mm}$ height and $450 \mathrm{~mm}$ width. The transmission system mounted on the frame consisted of a speed reduction gear box, main transmission shaft and chain and sprocket drive. The gear box used in the frame had a set of cast-iron bevel gears with 11 teeth on the pinion and 20 teeth on the gear. The transmission system could provide the tractor PTO speed of 540 to $300 \mathrm{rpm}$ for the rotor.

The shaft transmits the power from gearbox to the side drive (chain and sprocket). It is simply supported over two bearings and is welded on one side to the gear. It is $50 \mathrm{~mm}$ in diameter and $960 \mathrm{~mm}$ in length. The sprocket is keyed to the shaft with the help of a key. The shaft has a step of $7.5 \mathrm{~mm}$ on the sprocket side to account for mounting of bearing and The side drive consisted of a chain and sprocket arrangement that transmit the power coming from the gear box via a main transmission shaft to the rotor shaft. The chain and sprocket arrangement was modified to give velocity ratio of $2 / 3$, i.e. it reduces the output to $200 \mathrm{rpm}$ to the rotor shaft. The side drive used with a double strand chain of $30.75 \mathrm{~mm}$ pitch and two sprockets with two different diameters.

The roller chain consists of two rows of outer and inner plates. The outer row of plates is known as pin link or coupling link whereas the inner row of plates is called roller link. The pins are press fitted in the pin link and these pass through the bushing which are press fit in the roller links and join these, \#80 double strand roller chain has a pitch of $25.40 \mathrm{~mm}$ was used. The frame attached to the no till drill then the residue management device attached into the frame as shown in Figure 4. 


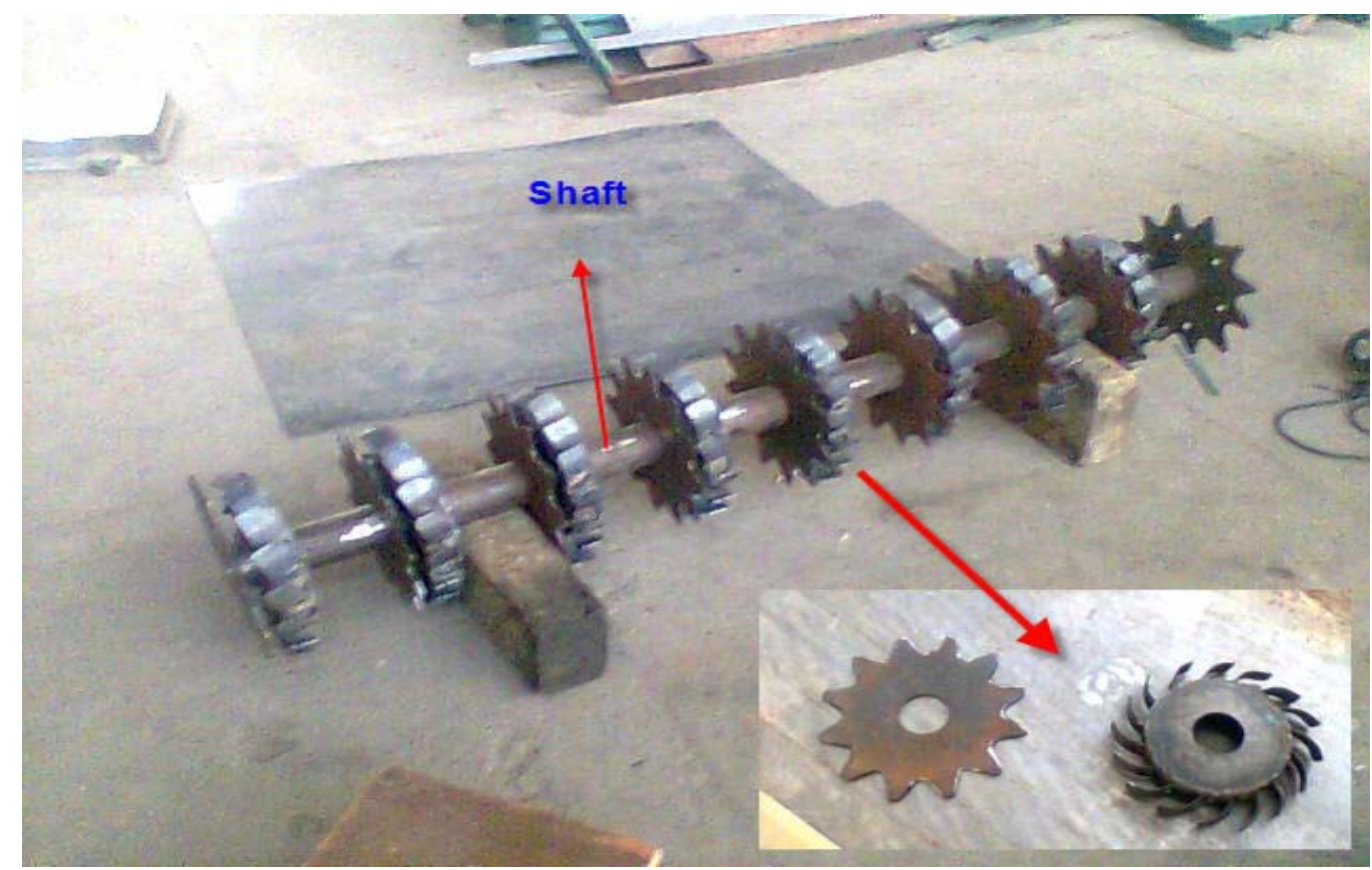

Figure 3. Arrangement of the residue manager parts on its shaft.

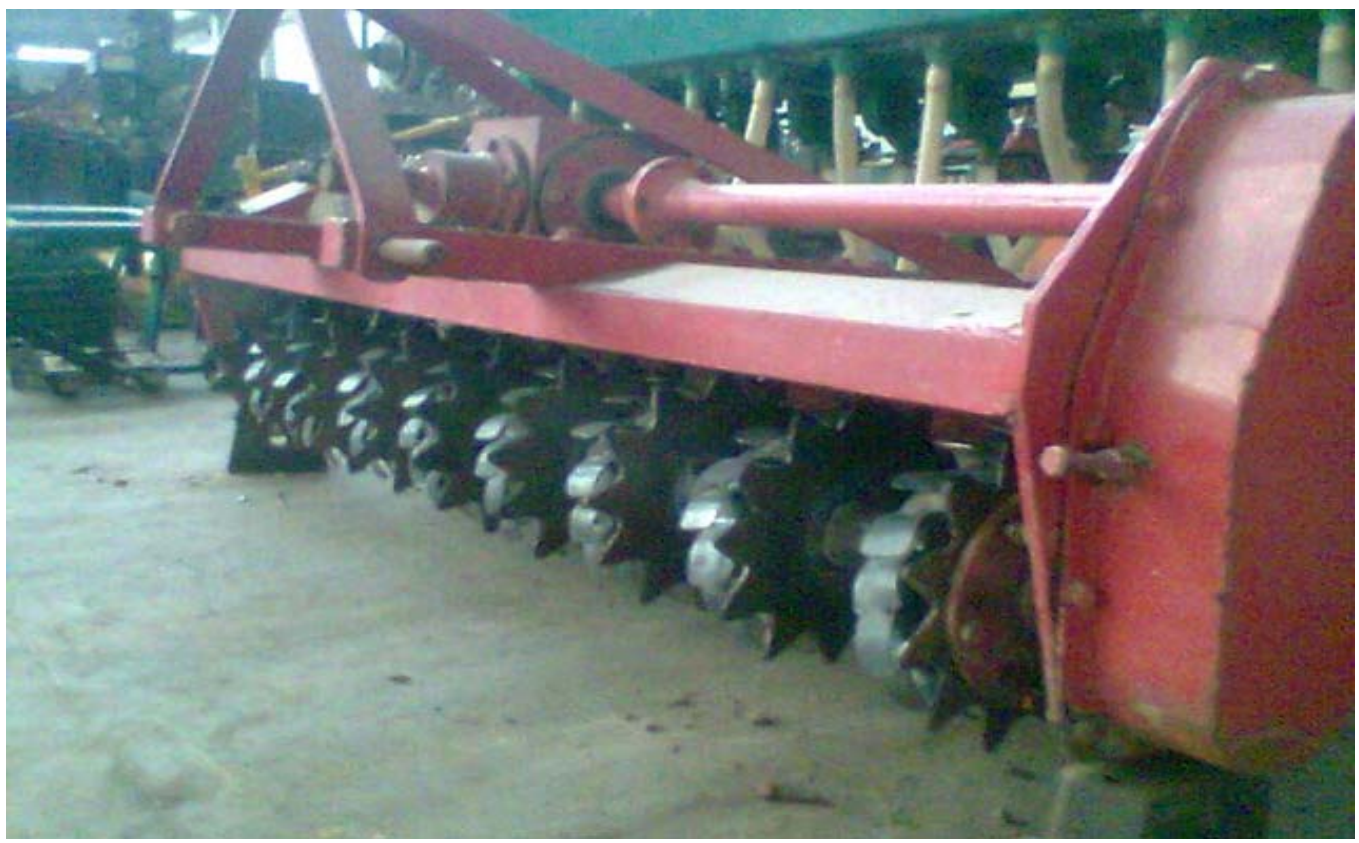

Figure 4 attaching the residue manager with the frame and the seed drill.

\subsection{Experiment Technique and Field Layout}

Field experiments were initiated during the year 2007-2008 on the research farm of the Department of Farm Power and Machinery, Punjab Agricultural University, Ludhiana, India. The soil at the experimental area was sandy loam with initial bulk density 1.34 $\mathrm{g} / \mathrm{cm}^{3}$. The values of moisture content and cone index were $13.5 \%$ and $3.8 \mathrm{MPa}$ respectively at the beginning of the experiments. Field experiments were carried out in 
combine harvested paddy field covered with standing stubble and loose straw above the surface without any change. The amount of loose residue found on field surface before sowing varied from 1468 to $3674 \mathrm{~kg} / \mathrm{ha}$ for all plots with average of $2535.1 \mathrm{~kg} / \mathrm{ha}$. While the amount of standing stubble found in field surface varied from 1256.3 to $2986.3 \mathrm{~kg} / \mathrm{ha}$ with average of $2144.6 \mathrm{~kg} / \mathrm{ha}$ for all plots.

The field experiments area was $1104 \mathrm{~m}^{2}$ divided into 6 plots laid down in randomized block design with three replications for all measurements and four replications in case of yield. Size of each plot was kept $23 \times 8 \mathrm{~m}$. An irrigated wheat (WL-343) variety was sown on November 28, 2007 and the recommended doze of fertilizer and seed rate of $112.5 \mathrm{~kg} / \mathrm{ha}$ were applied.

The no-till drill used in experiment was 9-row seed-cum-fertilizer drill which consists of frame, furrow opener, seed and fertilizer box, seed and fertilizer metering device and power transmission unit. In field experiment the randomized block design was followed in the study. The experimental data were analyzed statistically. The analysis of variance (ANOVA) used by using XLSTAT package and the critical difference at 1 and 5 per cent level of significance was observed for testing the significance of difference between the different treatments.

\section{RESULTS AND DISCUSSION}

\subsection{Fuel and Time Required}

To measure the fuel consumption during the experiments a separate fuel tank with 1 liter size was attached above the fuel injection pump. This fuel tank was connected to the fuel line through a connection and another connection was made to this fuel tank to collect the overflow of fuel. The time taken for completion of experiment in each plot was noted down by using a stop watch. From it the time taken was calculated in $\mathrm{h} / \mathrm{ha}$. The fuel consumption varied from 10.88 to $11.60 \mathrm{l} /$ ha for no-till drill with RME. In case of using no-till drill without RME fuel consumption varied from 7.82 to $8.10 \mathrm{l} / \mathrm{ha}$ as presented in table1.

Table 1. Effect of various treatments on no. of effective tiller, spike length, plant height, Fuel consumption and Time taken

\begin{tabular}{|c|c|c|c|c|c|c|}
\hline \multicolumn{2}{|c|}{} & $\begin{array}{c}\text { No. of } \\
\text { effective } \\
\text { tiller/m } \\
\text { length }\end{array}$ & $\begin{array}{c}\text { Spike } \\
\text { length, } \\
\mathrm{mm}\end{array}$ & $\begin{array}{c}\text { Plant } \\
\text { height, } \\
\mathrm{mm}\end{array}$ & $\begin{array}{c}\text { Fuel } \\
\text { consumptio } \\
\mathrm{n} \\
(1 / \mathrm{ha})\end{array}$ & $\begin{array}{c}\text { Time taken } \\
\text { (h/ ha })\end{array}$ \\
\hline $\begin{array}{c}\text { No-till } \\
\text { Drill with } \\
\text { RME }\end{array}$ & $\mathrm{R} 1$ & 93.08 & 110.79 & 886 & 11.44 & 1.94 \\
\cline { 2 - 7 } & $\mathrm{R} 2$ & 92.73 & 110.53 & 886 & 10.88 & 1.89 \\
\hline
\end{tabular}

R. A. Hegazy and I. S. Dhaliwal. Evaluation of a Power Driven Residue Manager for No-till Drills. Agricultural Engineering International: the CIGR Journal. Manuscript No.1641. Vol. 13, No.1, 2011. Provisional PDF Version. 


\begin{tabular}{|c|c|c|c|c|c|c|}
\hline & $\mathrm{R} 3$ & 93.17 & 109.42 & 886 & 11.60 & 1.96 \\
\cline { 2 - 7 } & Av. & 92.99 & 110.25 & 886 & 11.31 & 1.94 \\
\hline \multirow{2}{*}{$\begin{array}{c}\text { No-till } \\
\text { Drill } \\
\text { without } \\
\text { RME }\end{array}$} & $\mathrm{R} 1$ & 87.16 & 102.97 & 872 & 8.10 & 1.77 \\
\cline { 2 - 7 } & $\mathrm{R} 2$ & 86.86 & 102.46 & 872 & 7.82 & 1.68 \\
\cline { 2 - 7 } & R3 & 86.57 & 102.47 & 872 & 7.96 & 1.59 \\
\cline { 2 - 7 } & Av. & 86.86 & 102.63 & 872 & 7.96 & 1.68 \\
\hline \multicolumn{2}{|c|}{ S.D. } & 3.36 & 4.19 & 7.73 & 1.85 & 0.15 \\
\hline
\end{tabular}

The time required varied from 1.89 to $1.96 \mathrm{~h} / \mathrm{ha}$ for no-till drill with $\mathrm{RME}$, in case of using no-till drill without RME time required varied from 1.59 to $1.77 \mathrm{~h} / \mathrm{ha}$ (Table1). Statistical analysis showed that the different sowing machine had highly significant effect on fuel consumption with standard deviation 1.85. Also it showed that there was significant effect for different sowing machine on time required with standard deviation 0.15 (Table 1).

\subsection{Clogged Residue}

The clogged residues are the amount of residue clogged (clumped residue) with the notill drill or residue management device during sowing operation, this clogged residue is sticking to the wheels causing non-smooth rotations. Surface residue samples were collected before seeding from $1 \mathrm{~m}^{2}$ area from the field. The dry weight of residue was presented in terms of $\mathrm{kg} / \mathrm{ha}$. Clogged residue during sowing was collected from each opener up to $23 \mathrm{~m}$ run, the dried residue, free from soil was weighted and the amount of clogged residue was expressed as $\mathrm{kg} / \mathrm{ha}$.

The total amount of residues clogged under no-till drill with RME varied from 316.4 to $378.6 \mathrm{~kg} / \mathrm{ha}$ with $350.6 \mathrm{~kg} / \mathrm{ha}$ average. In case of no-till drill without RME the amount of residue clogged varied from 490.8 to $550.2 \mathrm{~kg} / \mathrm{ha}$ with $525.5 \mathrm{~kg} / \mathrm{ha}$ average. The amount of residue clogged decreased by $33 \%$ by using no-till drill with RME compared to no-till drill without RME (Fig. 5). Statistical analysis showed that using no-till drill with the residue manager had significant effect on amount of clogged residue with standard deviation 96.08 . 


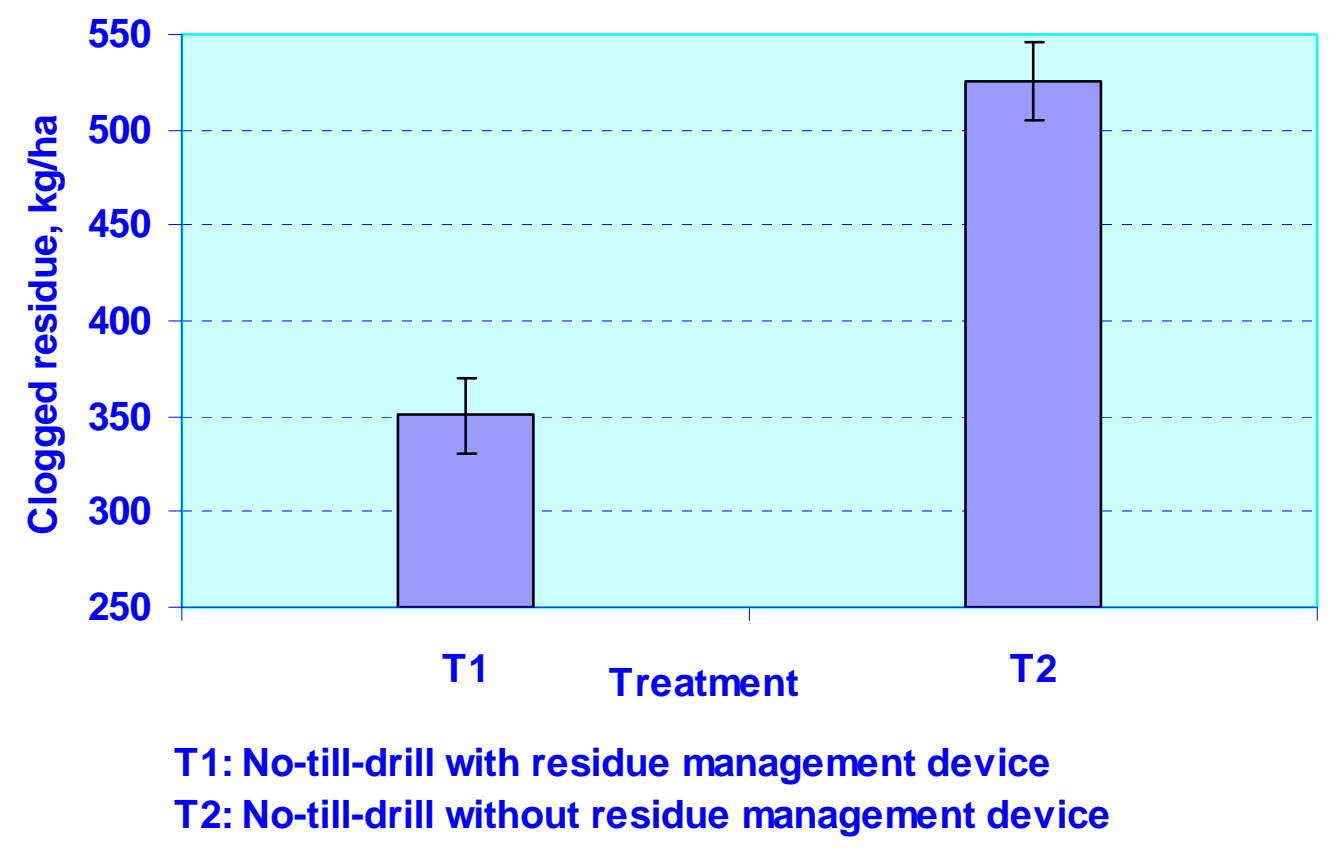

Figure 5. Effect of using the power driving residue manager on clogged residue.

\subsection{Cutting Standing Residue}

Standing residues before seeding from $1 \mathrm{~m}^{2}$ area from different locations in the field were noted. Cut numbers of stand stable (hills $/ \mathrm{m}^{2}$ ) were counted from three locations in each plot after running different the treatments. The number of hills recorded in all plots before sowing varied from $22-30 \mathrm{hill} / \mathrm{m}^{2}$. The number of cut hills/ $\mathrm{m}^{2}$ were observed after sowing and reported.

In case of using RME attached with no-till drill the numbers of cut hills were higher and the average percentage of cut hills varied from 58.32 to $70.04 \%$. Using no-till drill without RME gave percentage of cut hills from 9.10 to $24.08 \%$ which was much lower than using no-till drill with RME (Fig. 6). The reason is that using the RME can cut both loose and stands stubble which locates in front of the double wheel and remove them from the way of furrow openers. But in case of no-till drill without RME most of the standing stubbles easily pass between furrow openers without being cut. Statistical analysis showed that using no-till drill with the residue manager had significant effect on cutting standing residue with standard deviation 26.64 . 


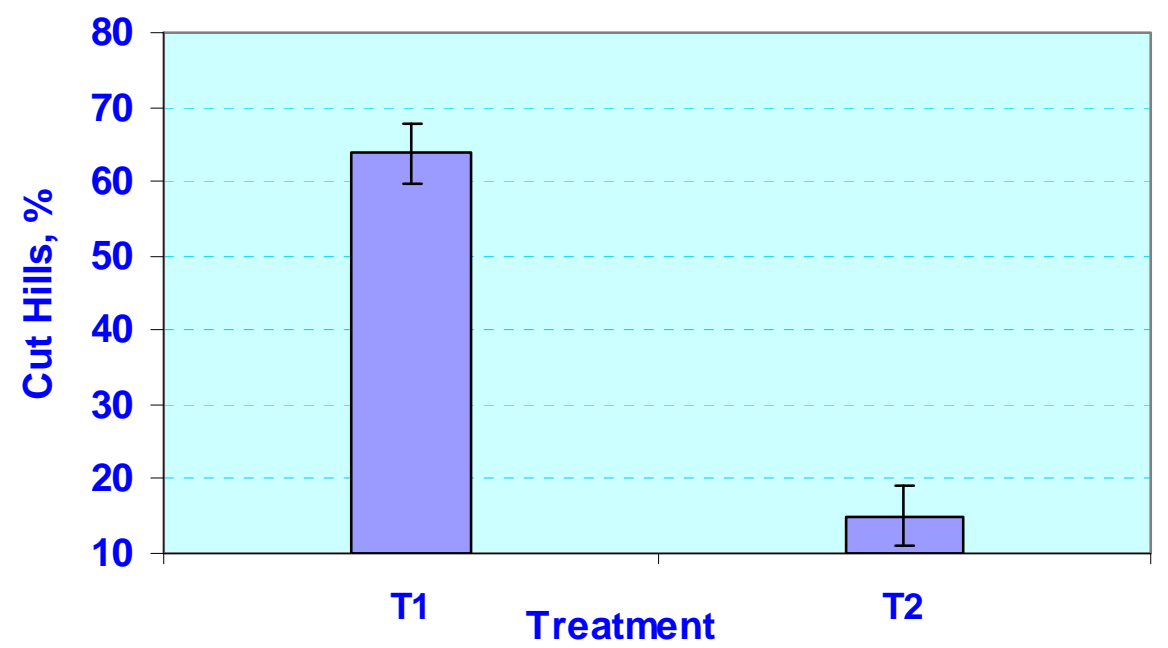

T1: No-till-drill with residue management device

T2: No-till-drill without residue management device

Figure 6. Effect of using the power driving residue manager on number of cut hill.

\subsection{Effective Tiller Count}

The yield of the crop will be based on number of effective tillers/m length. The effective tiller count was measured at harvesting stage from three places of one meter row length in each plot.

Effective tiller count/m length varied from 92.73 to 93.08 and from 86.57 to 87.16 for no-till with RME and no-till without RME respectively (Table1). The average number of effective tiller was higher in case of no-till drill with RME. Analysis of variance showed that different sowing machines had significant effect on no. of effective tiller per meter length with standard deviation 3.36 (Table 1).

\subsection{Spike length and Plant Height}

Measurement of spike length for selected plants in mm was done, Spike length varied from 109.42 to $110.79 \mathrm{~mm}$ and from 102.46 to $102.97 \mathrm{~mm}$ for no-till with RME and notill without RME respectively. The average number of effective tiller was higher in case of no-till drill with RME.

The average plant height varied from 886 to 886 and from 872 to $872 \mathrm{~mm}$ for no-till drill with RME and no-till drill without RME respectively (Table1). The average plant height was higher in case of no-till drill with RME followed by no-till without RME. Analysis of variance showed that different sowing machines had significant effect on the length of spike and highly significant effect on plant height with standard deviation 4.19and 7.73 respectively (Table 1 ). 


\subsection{Grain Yield}

Manually harvested samples of each $1 \mathrm{~m}^{2}$ were taken from each plot. The weight of each sample (grain + straw) was taken. The samples were threshed with a plot thresher. The threshed grains were weighed and yield per hectare was calculated.

The grain yield varied from 3798 to $5397 \mathrm{~kg} / \mathrm{ha}$ with total average of $4593.2 \mathrm{~kg} / \mathrm{ha}$ in case of using no-till drill with RME. Using no-till drill without RME gave grain yield varied from 3301 to $4897 \mathrm{~kg} / \mathrm{ha}$ with total average of $4024.1 \mathrm{~kg} / \mathrm{ha}$ (Table 2). Using notill drill with residue management device increased the yield by $12.4 \%$ more than using no-till drill without RME. Analysis of variance as presented in Table 3 showed that using no-till drill with the residue manager had significant effect on grain yield with standard deviation 337.20.

Table 2 Effect of various treatments on grain yield

\begin{tabular}{|c|c|c|c|c|c|c|}
\hline Treatments & \multicolumn{6}{|c|}{ Grain Yield, kg/ha } \\
\hline \multirow{5}{*}{$\begin{array}{l}\text { No-till Drill } \\
\text { with Residue } \\
\text { Management } \\
\text { Device }\left(\mathrm{T}_{1}\right)\end{array}$} & & $\mathrm{R} 1$ & $\mathrm{R} 2$ & R3 & R4 & Average \\
\hline & $\mathrm{P} 1$ & 5397 & 4894 & 4279 & 5489 & 5014.8 \\
\hline & $\mathrm{P} 2$ & 4824 & 3958 & 5123 & 4665 & 4642.5 \\
\hline & P3 & 3798 & 4136 & 4014 & 4541 & 4122.3 \\
\hline & $\begin{array}{c}\text { Total } \\
\text { Average }\end{array}$ & 4673 & 4329.3 & 4472 & 3898.3 & 4593.2 \\
\hline \multirow{5}{*}{$\begin{array}{c}\text { No-till Drill } \\
\text { without Residue } \\
\text { Management } \\
\text { Device }\left(\mathrm{T}_{2}\right)\end{array}$} & $\mathrm{P} 1$ & 3496 & 4821 & 4879 & 3641 & 4209.25 \\
\hline & $\mathrm{P} 2$ & 4038 & 3713 & 3971 & 4330 & 4013.0 \\
\hline & $\mathrm{P} 3$ & 3803 & 4137 & 4161 & 3301 & 3850.5 \\
\hline & $\begin{array}{c}\text { Total } \\
\text { Average }\end{array}$ & 3779 & 4223.6 & 4337 & 3757.2 & 4024.1 \\
\hline & S.D. & \multicolumn{5}{|c|}{337.20} \\
\hline
\end{tabular}

P1, P2 and P3: Plots $\quad$ S.D.: Standard Deviation $\quad$ R1, R2 .....R4: Replications 
Table 3: Analysis of variance (ANOVA) and standard deviation for the variables

\begin{tabular}{|l|l|l|}
\hline \multicolumn{1}{|c|}{ Variable } & \multicolumn{1}{c|}{ F } & \multicolumn{1}{c|}{ Pr $>$ F } \\
\hline No. of effective tiller/m length & 226.423 & 0.004 \\
\hline Spike length, mm & 169.404 & 0.006 \\
\hline Plant height, mm & 39616.404 & $<0.0001$ \\
\hline Fuel consumption ( / / ha ) & 135.033 & 0.007 \\
\hline Time taken (h/ ha ) & 6.033 & 0.145 \\
\hline Clogged Residue & 276.575 & 0.004 \\
\hline Cutting Standing Residue & 14.718 & 0.064 \\
\hline Grain yield, kg/ha & 1.954 & 0.304 \\
\hline
\end{tabular}

\section{Conclusion}

Adding the power driven residue manager as an attatchment for no-till drillls can increase their ability for working under diffucult field conditions. Using this unit under above mentioned expremints decreased the amount of residue clogged by $33 \%$, which make sowing wheat in this condition more easly and reduce interface occured to the notill drills. Using the residue manager with no-till drill also increased number of cut hill by $76.6 \%$, which increase the possibility for uniform sowing in combine harvested rice fields. Effective tiller count, Spike length and plant height were high in case of using no-till drill with the residue manager, which increased the grain yield by $12.4 \%$ more than using no-till drill without this attachment. Allthough, using this attachment will increase fuel consumption and power reuired for sowing wheat, but it has many features related to crop response and yield, which will be more economically and has many benifites for farmers.

\section{REFERENCES}

Bianchini, A. 2002. Desenvolvimento teo' rico experimental de disco de corte dentado passivo para corte de palhic, o em cana-de-ac, $\mathrm{u}^{\prime}$ car [Theoretical and experimental development of tooth coulter for cutting sugar cane residue] $\mathrm{Ph}$. D. thesis. Faculdade de Engenharia Agrí cola, Unicamp, Brazil.

Carter, M. R. 1994. A review of conservation tillage strategies for humid temperate regions. Soil \&Till. Res. 31: 289-301.

Dawn Company. 2001. Planting 2001 News. Dawn Equipment Company, Illinois, USA, http://www.dawnequipment.com. Accessed on February, 2007.

Desbiolles, J. 2004. Mechanics and features of coulter openers in zero tillage applications.www.unisa.edu.au/amrdc/SeedTrls. Accessed in December, 2006. 
Manjeet, S. and L. N. Shukla. 2006. Design Optimization of No-Till Drill Components by Using Finite Element Analysis (FEA). Computers in Agriculture and Natural Resources, $4^{\text {th }}$ World Congress Conference, Proceedings of the 24-26 July 2006. Orlando, Florida, USA.

Mckyes, E. 1985. Soil Cutting and Tillage. Elsevier, New York, p: 217.

Morrison, J. E. and T. J. Gerik. 1985. Planter depth-control: I. Predictions and projected effects on crop emergence. Transaction of the ASAE 28(5): 1415-1418.

Siemens, M. C. and D. E. Wilkins. 2006. Effect of residue management methods on No-till drill performance. Applied Engineering in Agriculture 22(1): 51-60.

Siemens, M. C., D. C. Wilkins and R. F. Correa. 2004. Development and evaluation of a residue management wheel for Hoe-type no-till drill. Transaction of the ASAE 47 (2): 397:404.

Singh, B. and T. P. Singh. 1995. Zero-till fertilizer seed drill, a machine for timely sowing of wheat. Indian Farmer Digest 28, P: 15.

Slattery, M. G. 1998. A study of the balance of tine pattern factors for operating in wheat stubble. SAEAg. Paper No. 98/044. Barton, Australian Capital Territory. SAEAg.

Slattery, M. G. and T. Riley. 1996. The influence of tine parameters on stubble handling ability. SEAg Paper No. 96/017. Barton, Australian Capital Territory: SAEAg.

Vincent, D. and D. Quirke. 2002. Controlling Phalaris minor in the Indian rice-wheat belt. ACIAR Impact Assessment Series No. 18.

Wang, Q. H., Y.Z. Jin , H. L. Li and Z.X. Wenyin. 2008. Design and Experiment on Powered Disc No-tillage Planter for Ridge-tillage. Transactions of the Chinese Society for Agricultural Machinery. 2008-06.

Wilkins, D. E., D.A. Haasch and P.E. Rasmussen. 1983. Grain drill modifications for improved operation in surface residues. In 1983 Columbia Basin Agricultural Research Center Research Report, 14-15. SR 680. Corvallis, Ore: Oregon State University Agricultural Experiment Station in cooperation with USDA-ARS, Pendleton, Oregon.

Yetter Company. 2003. Yetter Manufacturing Product Catalog. Colchester, Yetter Manufacturing Co. Available at: www.yetterco.com. Accessed in October, 2006. 